\title{
À procura da vida: pensando com Gregory Bateson e Tim Ingold a respeito de uma percepção sagrada do ambiente
}

\section{Gustavo Ruiz Chiesa}

- Universidade Federal do Pampa / Uruguaiana, RS, Brasil

$\boldsymbol{\nabla}$ gustavorchiesa@gmail.com

\section{RESUMO}

No presente artigo pretende-se introduzir algumas das principais noções e conceituações elaboradas por dois influentes antropólogos britânicos: Gregory Bateson (1904-1980) e Tim Ingold (1948-). Ao longo do texto, articulando uma reflexão ao redor de certas categorias desenvolvidas por esses autores, proporemos a ideia de uma percepção sagrada atenta às relações que atravessam e constituem todos os seres e coisas que habitam o mundo. Uma maneira de perceber, conhecer e se engajar no ambiente que, sem abrir mão dos sonhos e da imaginação, concebe outras formas possíveis de viver a vida e se corresponder com tudo aquilo que nos envolve. 


\section{INTRODUÇÃO}

Em 21 de março de 1946, o neurologista e matemático Warren McCulloch (18991969), acompanhado de seus colegas, também matemáticos, Norbert Wiener (1894-1964) e John von Neumann (1903-1957), resolve retomar um evento iniciado quatro anos antes pela fundação filantrópica Josiah Macy Jr. (ou Macy Fondation) com o intuito de estabelecer as bases de uma "nova ciência geral do funcionamento da mente humana". Sob o título de "Mecanismos de retroalimentação e sistemas de causação circular em sistemas biológicos e sociais" (Feedback Mechanisms and Circular Causal Systems in Biological and Social Systems), o evento contou com a participação de renomados matemáticos, físicos, psicólogos, filósofos, antropólogos, biólogos, engenheiros e neurocientistas, todos interessados no desenvolvimento de uma linguagem científica comum, capaz de atravessar e conectar diferentes especialidades e modalidades de ciência. Tal empenho resultou na criação da cibernética ou "ciência da regulação e da comunicação no animal e na máquina" (Wiener, 1948). Do grego kybernetes (timoneiro ou piloto), a expressão serviria como uma metáfora para a "pilotagem", "direção", "regulação" ou "controle" de sistemas materiais e orgânicos, e exerceria um enorme impacto para o desenvolvimento de uma perspectiva sistêmica sobre a vida (Capra, 1996).

As conferências realizadas naquela ocasião giraram em torno de temas relacionados à analogia, sugerida por von Neumann, entre computador e cérebro; ao uso da lógica matemática para compreender o funcionamento cerebral; à concepção de realimentação (feedback) desenvolvida por Wiener; e, finalmente, à revisão do repertório de conceitos estabelecidos nas ciências humanas e sociais a partir de reflexões inspiradas nas novas ideias trazidas pela cibernética. Esse último ponto foi sugerido e apresentado pelo casal de antropólogos Gregory Bateson (1904-1980) e Margaret Mead (1901-1978). Em que consistiam essas novas ideias? Em linhas gerais, o que chamou a atenção especialmente de Bateson foi a centralidade das concepções de realimentação, autorregulação e auto-organização para o pleno entendimento da dinâmica da vida. A ideia-chave de que existe um padrão geral de organização da vida-aplicável tanto aos organismos, quanto às configurações sociais, que se conecta e se perpetua em diferentes camadas da realidade-, também parece ter o entusiasmado, bem como o caráter eminentemente interdisciplinar daquelas proposições (Capra,1996). Não só Wiener, mas todos os chamados "ciberneticistas" exerceram grande influência sobre as ideias de Bateson e os possíveis rumos (científicos) que tomaria a partir daquele momento.

A mente de Bateson, como a de Wiener, passeava livremente por entre as 
disciplinas, desafiando as suposições básicas e os métodos de várias ciênciase procurando padrões gerais e convincentes abstrações universais. Bateson considerava-se basicamente um biólogo, e tinha os muitos campos em que se envolveu - antropologia, epistemologia, psiquiatria e outros-por ramos da biologia. A grande paixão que trouxe à ciência abrangeu a plen a diversidade dos fenômenos associados com a vida, e seu principal objetivo era descobrir princípios de organização comuns nessa diversidade - "o padrão que conecta", como se expressaria muitos anos mais tarde. Nas conferências sobre cibernética, tanto Bateson como Wiener procuraram por descrições abrangentes, holísticas, embora tivessem cuidado para não se afastar do âmbito definido pelas fronteiras da ciência. Assim, criaram uma abordagem sistêmica para uma ampla gama de fenômenos (Capra, 1996: 58).

Voltando à ideia de realimentação desenvolvida por Wiener, o matemático (e também filósofo) observou nela o mecanismo essencial da homeostase, isto é, "a autorregulação que permite aos organismos vivos se manterem num estado de equilíbrio dinâmico" (Capra, 1996: 60). No entanto, o exemplo utilizado para explicar essa ideia não veio inicialmente dos sistemas vivos, mas sim da palavra ou, mais exatamente, da função que deu origem à expressão cibernética.

Quando o barco se desvia do seu curso prefixado-digamos, para a direita-o timoneiro avalia o desvio e então esterça no sentido contrário, movendo, para isso, o leme para a esquerda. Isso reduz o desvio do barco, talvez até mesmo a ponto de o barco continuar em sua guinada e ultrapassar a posição correta, desviando-se para a esquerda. Em algum instante durante esse movimento, o timoneiro esterça novamente para neutralizar o desvio do barco, esterça no sentido contrário, esterça novamente para contrabalançar o desvio, e assim por diante. Desse modo, ele conta com uma realimentação contínua para manter o barco em sua rota, sendo que a sua trajetória real oscila em torno da direção prefixada. A habilidade de guiar um barco consiste em manter essas oscilações as mais suaves possiveis (Capra, 1996: 58).

Uma máquina, um organismo vivo ou mesmo um ecossistema inteiro que apresentasse a capacidade de se auto-organizar ou de se realimentar continuamente tenderia, portanto, a esse permanente estado de equilíbrio dinâmico ou homeostase. Porém, qualquer perturbação brusca ou imprevista que interferisse no comportamento ou na dinâmica desse sistema poderia, de algum modo, colocar em risco o seu equilíbrio e a sua própria existência.

Num ecossistema, por exemplo, cada espécie tem potencial para experimentar 
um crescimento exponencial de sua população, mas essa tendência é mantida sob contenção graças a várias interações equilibradoras que operam dentro do sistema. Crescimentos exponenciais só aparecerão quando o ecossistema for seriamente perturbado. Então, algumas plantas se converterão em "ervas daninhas", alguns animais se tornarão "pestes" e outras espécies serão exterminadas, e dessa maneira o equilíbrio de todo o sistema será ameaçado (Capra, 1996: 64).

Outro argumento muito debatido durante as "conferências Macy" e que posteriormente seria reelaborado e criticado pelos próprios ciberneticistas e seus seguidores consistiu na analogia estabelecida entre cérebro e computador, supondo que ambos operavam por meio de mecanismos capazes de processar informações e manipular certos símbolos a partir de um conjunto de regras preexistentes. Tal ideia, lembra Capra (1996), dominou a chamada neurobiologia ao menos até a década de 1970, período em que as ciências cognitivas começaram a revisar as teorias propostas pela cibernética - sem rejeitar a dimensão interdisciplinar e a interpretação sistêmica que a consagrou - e propor um novo modelo para o entendimento da mente. A crítica fundamental a essa metáfora computacional rejeitava qualquer possibilidade de comparação entre a inteligência humana e a inteligência da máquina. "O sistema nervoso humano não processa nenhuma informação (no sentido de elementos separados que existem já prontos no mundo exterior, a serem apreendidos pelo sistema cognitivo), mas interage com o meio ambiente modulando continuamente sua estrutura" (Capra, 1996: 68). Além disso, a inteligência, a memória e o pensamento humano são sempre contextualizados e carregados de emoções, sentimentos, sensações ou repercussões corporais. O cérebro ou o sistema nervoso não opera por meio de uma sequência de regras abstratas previamente determinadas ou através de um processador lógico central responsável por armazenar informações em um local específico. Ao contrário, "os cérebros parecem operar com base numa conexidade generalizada, armazenando distributivamente as informações e manifestando uma capacidade de auto-organização que jamais é encontrada nos computadores" (Capra, 1996: 69). Trata-se, nesse sentido, da passagem dos símbolos para conexidade, das regras locais para coevência global, do processamento de informações para as propriedades emergentes das redes neurais (Capra, 1996: 209), ou, mais do que isso, "do predomínio paradigmático do mundo inanimado da física mecânica (o mundo das bolas de bilhar se chocando numa imagem repetida por Bateson) para um paradigma oriundo dos sistemas biológicos e sociais com direito a uma crítica à concepção de sujeito desvinculado de seu objeto" (Velho, 2010: 3).

Esse olhar para as conexões, interações e transformações, para o sistema em sua totalidade, para o padrão que liga, ajudaria, na visão de Bateson, a produzir 
uma compreensão mais interessante a respeito do ambiente, da mente e da própria vida. Assim, baseando-se nos princípios cibernéticos, ele tentará superar certas visões (e divisões) de mundo há muito estabelecidas e propor uma outra leitura, uma outra epistemologia, uma outra maneira de ver, de fazer ciência e de se relacionar com nós mesmos e com tudo aquilo que nos envolve. Uma ciência das relações, dos caminhos, dos movimentos, dos improvisos, dos processos, que nos ajuda a ver e pensar o mundo de uma forma diferente, menos dicotômica, mais fluida, ou, se quisermos, menos binarista, mais cromática. Uma ciência "indisciplinar" ou "antidisciplinar", afirmaria Ingold (2013: 12), que transcende as fronteiras dos saberes ao apostar na continuidade inerente à vida. Comecemos, então, a explorar um dos lados dessa "indisciplina" a partir de um autor cuja influência batesoniana (e, indiretamente, da cibernética) é por ele próprio reconhecida'.

\section{A TEIA DA VIDA}

Logo na introdução de Being Alive: Essays on Movement, Knowledge and Description (2011), o antropólogo britânico Tim Ingold deixa claro um de seus maiores objetivos acadêmicos e conceituais: trazer a antropologia de volta à vida, ou melhor, trazer a vida de volta à antropologia. Para ele, nossa disciplina esteve excessivamente preocupada em estabelecer códigos, modelos, estruturas, esquemas, esquecendo-se de sua vocação primordial, qual seja, a de investigar as condições e potencialidades da vida humana. A antropologia, portanto, expulsou a vida de suas análises tornando-se uma disciplina fragmentada (e fragmentadora), fechada para perceber o mundo tal como vivenciado ou experimentado por aqueles que o habitam. As pessoas, argumenta, não devem ser entendidas como fragmentos isolados e acabados, pois elas vivem e percebem o mundo não como dividido em blocos cristalizados, mas sim como um processo contínuo. Para dar conta deste mundo contínuo e dos seres que nele habitam é preciso fazer uso de uma nova linguagem, uma nova abordagem que esteja necessariamente atenta aos processos, aos fluxos, aos movimentos e às transformações constitutivas da vida. Em que consistiria essa abordagem? Ou antes, em que consistiria, afinal de contas, a vida?

A vida, explica Ingold, não começa aqui ou termina ali, não conecta pontos de origem com algum lugar final. Ao contrário, ela mantém o seu curso, segue em frente, improvisando caminhos em meio às inúmeras coisas encontradas em seu percurso. Superando divisões (e dimensões) limitadoras da realidade, diríamos que a vida é, numa única sentença, um movimento de abertura (2011: 4).

A sugestão de pensar a vida enquanto movimento, ideia-chave da proposta de Ingold (presente inclusive no subtítulo do livro acima mencionado), foi,
1 Foge aos objetivos deste artigo realizar uma análise exaustiva dos autores abordados no decorrer dessas páginas. A enorme complexidade e vastidão das obras de Gregory Bateson e Tim Ingold certamente fornece material não para um único artigo, e sim para inúmeras dissertações, teses e livros. Também não é um dos propósitos deste ensaio demonstrar de que maneira um autor foi (ou não) influenciado pelas ideias do outro. Se isso em alguns momentos acontece é apenas com a intenção de melhor orientar $\mathrm{o}$ argumento do texto, aproximando e fazendo convergir as ideias de ambos os autores (encontradas em diferentes momentos de suas trajetórias) para a proposta de uma percepção sagrada do ambiente, tal como será apresentada adiante. 
segundo ele, abandonada pela antropologia. No entanto, para entender melhor esse abandono, precisaremos recuperar a crítica que o próprio autor realiza, em diferentes ensaios, a certos teóricos relacionados ao que se convencionou chamar de cultura material e tese da complementaridade. Desse modo, e de maneira concomitante a essa crítica, seremos introduzidos a uma abordagem teórica e conceitual que esteja de fato à procura da vida.

Ingold (2011: 20) afirma que os antropólogos e arqueólogos preocupados com a materialidade ou a cultura material - grupo que inclui nomes como os de Daniel Miller (2005) e Christopher Tilley (2007) - têm, na verdade, pouco a dizer sobre os materiais de que são feitas as coisas. Aqui, centrando o argumento nas ideias de vida e movimento, ele faz uma clara distinção entre coisa e objeto, procurando com isso se distanciar das análises que pretende criticar. O mundo que habitamos, diz ele, não é composto por objetos e sim por coisas. Uma árvore, por exemplo, não é um objeto, mas sim um agregado de fios vitais. Citando Heiddeger em seu famoso ensaio denominado A coisa (1971), Ingold dirá que:

O objeto coloca-se diante de nós como um fato consumado, oferecendo para nossa inspeção suas superfícies externas e congeladas. Ele é definido por sua própria contrastividade com relação à situação na qual ele se encontra (Heidegger 1971: 167). A coisa, por sua vez, é um "acontecer", ou mel hor, um lugar onde vários aconteceres se entrelaçam. Observar uma coisa não é ser trancado do lado de fora, mas ser convidado para a reunião (2012b: 29).

As coisas não são ou estão fechadas e acabadas, prontas para serem consumidas $^{2}$. Um prédio não está fixado, repousando sobre a superfície terrena, como parece conceber o arquiteto em seu projeto, esperando apenas o momento em que será ocupado por seus moradores. Um prédio ou uma casa "real" está viva, se transformando, se decompondo, sendo habitada por seres que não percebemos. Assim, nesse sentido, ela nunca está pronta, mas sim envolvida em um permanente processo de transformação, o que exige de seus moradores um enorme esforço para a sua manutenção. A casa, assim como a árvore, "é uma reunião de vidas, e habitá-la é se juntar à reunião-ou, nos termos de Heidegger, participar com a coisa na sua coisificação" (Ingold, 2012b: 30). Logo, somos parte e participamos do processo de transformação das coisas, ajudando a confeccionar o mundo que habitamos. Habitar o mundo é, nesse sentido, participar de seu processo de formação e transformação.

As coisas, além disso, não podem ser pensadas fora de seus ambientes. Fazer isso implica tirar-Ihes a vida, cortar seus movimentos. Um pássaro não pode ser entendido isolado do ar que o possibilita voar. O mesmo vale para o peixe caso seja retirado da água. Pois "o pássaro é o seu voar; o peixe, o seu nadar"
2 Ingold (2011: 26) chama a atenção para o fato desses estudiosos da cultura material estarem preocupados com os processos de consumo e não com a produção, o que revelaria o interesse de tais pesquisadores por objetos em alguma medida já cristalizados e separados dos fluxos de materiais e suas transformações (cristalizações ou estabilizações que são sempre, vale lembrar, provisórias). 
(Ingold, 2012b: 33). Separados de seus ambientes, isolados de seus meios, as coisas perdem movimento, interrompem seus fluxos que lhes asseguram a vida, tornando-se meros objetos "mortos". Nesse ponto reside a crítica de Ingold àqueles que, tais como Alfred Cell (1998), tentam atribuir agência aos objetos. No mundo de objetos sólidos previsto pelos teóricos de cultura material o fluxo de materiais é interrompido, sufocado e silenciado. Não há respiração; não há vida. Retiradas do fluxo, as coisas morrem, se cristalizam. Para tentar reanimá-las, tais teóricos, de maneira mágica, Ihes atribuem agência, incorrendo em uma dupla redução: das coisas aos objetos, da vida à agência (Ingold, 2012b: 34). Ingold afirma que as coisas se movimentam, se transformam, crescem, não porque possuem agência e sim porque estão vivas. Portanto, trazer as coisas de volta à vida não é adicionar agência, mas sim "restaurá-las em seus fluxos generativos do mundo de materiais em que surgiram e continuam a existir" (2011: 29). Não se trata de ver a vida nas coisas, mas sim que as coisas estão na vida ou estão vivas. Finalmente, as coisas têm vida não porque são dotadas de uma força sobrenatural que as anima, mas sim porque estão imersas em um fluxo criativo contínuo e formam um feixe de linhas de fuga.

É no contrário da captura e da contenção-na descarga e vazamento-que descobrimos a vida das coisas. Com isso em mente, podemos voltar a Deleuze e Cuattari (2004: 451), que insistem que onde quer que encontremos matéria, esta é "matéria em movimento, em fluxo, em variação"; e a consequência, continuam eles, é que "essa matéria-fluxo só pode ser seguida" (Ingold, 2012b: 37).

Seguir os materiais, acompanhar seus processos de infinita transformação, esse é o desafio que Ingold nos apresenta. Seguir envolve itineração, criatividade e improvisação. Como itinerantes que improvisam criativamente seus caminhos, devemos "seguir os modos do mundo à medida que eles se desenrolam, e não conectar, em retrospecto, uma série de pontos já percorridos" (Ingold, 2012b: 38). Aventure-se! Junte-se ao mundo e misture-se nele, recomendam Deleuze e Guattari (1995). A vida se desenrola ao longo de linhas-fios, de fuga, de devir, que não conectam, mas que estão entre, ou melhor, ao longo de. Na vida "os pontos não são conectados, mas colocados de lado e tornados indiscerníveis pela corrente à medida que ela se arrasta através deles. A vida está sempre em aberto: seu impulso não é alcançar um fim, mas continuar seguindo em frente" (Ingold, 2012b: 38). E seguir em frente é improvisar.

A vida não é, contudo, uma só linha ou um campo de linhas e pontos interconectados, mas sim um emaranhado de linhas que formam uma teia ou malha (meshwork) e que possibilitam a nossa percepção e a nossa ação no mundo. Como os fios de uma teia de aranha, tais linhas são as condições de possibilidade de per- 
manência e continuidade de toda a vida. "Elas não são, em si, linhas de interação. Se essas linhas são relações, então elas são relações não entre, mas ao longo de". Assim, a teia da vida (bem como a da aranha) é formada por múltiplas linhas de crescimento que estão "enredadas em um centro mas deixando inúmeras 'pontas soltas' nas periferias". Independentemente da imagem ou metáfora escolhida, a ênfase deve estar "no caráter fluido do processo vital, onde os limites são sustentados graças ao fluxo de materiais através deles" (Ingold, 2011: 85-86).

A ideia de processo vital também serve de base para a crítica que Ingold $(2001 ; 2008)$ realiza aos propagadores da tese da complementaridade 3 . Estes, em seu entendimento, não são capazes de oferecer uma explicação coerente que leve em conta o processo de desenvolvimento ontogenético que perpassa qualquer organismo vivo. Ao contrário, tal argumento sugere que os seres humanos são em parte pré-constituídos geneticamente, em parte moldados através da superposição de estruturas já estabelecidas (trata-se dos chamados procedimentos de enculturação ou socialização). Assim, uma análise orientada pela lógica da complementaridade preconiza que as formas que um corpo humano apresenta (derivadas de seu genótipo ou do desenho básico pré-definido), as suas capacidades intelectuais (armazenadas em sua mente ou em suas "estruturas mentais inatas") e os seus modos de conduta (definidos por sua cultura, ou seja, pelo sistema de símbolos e representações culturais pré-existentes) são necessariamente anteriores e independentes ao envolvimento e desenvolvimento desse ser humano em seu contexto prático em um ambiente no qual se insere e participa de maneira ativa. Logo, se somarmos essas três diferentes e complementares dimensões da vida, chegaríamos a uma análise completa, a um perfeito entendimento do ser humano.

É contra esse tipo de argumento que ele apresentará uma alternativa possível para pensar a vida humana de uma maneira integrada e antidisciplinar (i.e., sem apresentar divisões disciplinares). Tal perspectiva será denominada de abordagem da obviação (obviation approach). Aqui, a preocupação não está em juntar dimensões consideradas separadas para compor uma "totalidade biopsicossocial", mas sim acabar com os limites pelos quais estes componentes (corpo, mente e cultura) foram distinguidos e estas disciplinas (biologia, psicologia e antropologia) fragmentadas. Nessa abordagem, o ser humano será entendido não como "uma entidade compósita feita de partes separáveis, mas complementares entre si, e sim como um lócus singular de crescimento criativo dentro de um campo continuamente desdobrado de relacionamentos" (Ingold, 2001, p. 256). Tal compreensão é, em grande medi$\mathrm{da}$, herdeira do pensamento cibernético descrito no início deste ensaio. Como afirma Ingold, em entrevista concedida a Octavio Bonet, Clara Mafra, Rosane Prado e Otávio Velho,
3 Sem mencionar nomes específicos, Ingold (2008) direciona sua crítica aos propositores e praticantes das assim chamadas "biologia evolucionista", "ciência cognitiva" e "teoria cultural". 
a cibernética foi precursora daquilo que hoje se chama de uma abordagem relacional das coisas, que percebe o mundo em que vivemos não como sendo constituído de entidades particulares individuais, mas de movimento, relações e fluxos, que vê o mundo como fundamentalmente dinâmico em seu movimento, e as coisas que observamos nele como emergindo desse movimento. Istoé básico na abordagem que eu quero desenvolver... (ênfases minhas, Ingold apud Bonet et al, 2014: 311).

Concebendo o humano como um ser que ocupa dois lugares distintos, a tese da complementaridade advoga que todo ser humano é uma pessoa social e um organismo natural. Ao contrário, na abordagem da obviação o ser humano é tratado como um todo pessoa-organismo que habita um ambiente cercado por outros seres, humanos e não-humanos. Logo, nós não formamos ou participamos de um universo social separado de um "reino natural", mas habitamos um mesmo ambiente constituído por um complexo sistema de relações, sendo atravessado por inúmeras linhas ou forças, que nos conectam e nos afetam. Tal ambiente, e a maneira como nos relacionamos e interagimos com ele, é o que torna possível o desenvolvimento de nossa percepção, nossa memória e nosso aprendizado (Ingold, 2008).

Assim, em última instância, as formas e as capacidades humanas (e de outros organismos não-humanos) não são atributos, por exemplo, de uma herança genética, e sim das potencialidades criativas do sistema em desenvolvimento, ou seja, do sistema inteiro de relações constituído pela presença da "pessoa-organismo" em seu ambiente concreto. Desse modo, não existe algo como uma natureza humana, ou uma essência pré-programada e separada da realização de nossas atividades no tempo e no espaço real, justamente porque nossas habilidades e potencialidades não estão dadas ou fixadas em um passado anterior, mas, ao contrário, continuam evoluindo e sendo criadas no decurso de nossas vidas diárias. Em resumo, trata-se das habilidades práticas incorporadas e apreendidas no decorrer de nossa vida, isto é, do nosso processo de desenvolvimento enquanto organismos vivos envoltos em um ambiente de relações com outros organismos humanos e não-humanos.

O que teoricamente serviria de base conceitual e filosófica para ambos os modelos analíticos questionados - tanto o da cultura material como o da tese da complementaridade - seriam as já mencionadas distinções e/ou polarizações entre natureza e cultura, corpo e mente, forma e substância, matéria e espírito, ser e ambiente, indivíduo e coletivo, e assim por diante (Ingold, 2008, 2012b). Tais teorias percebem o ambiente de maneira indireta, ou seja, as pessoas não acessam o mundo diretamente tendo que construi-lo através da matéria-prima adquirida a partir dos sentidos. Fazendo isso, aponta Ingold, tais modelos pos- 
tulam implicitamente a separação cartesiana entre mente e corpo. Os sentidos pertencem ao corpo (nascemos com eles, são dados pela natureza), mas os padrões de significado, os conteúdos simbólicos, são construídos pela mente através do processo de enculturação. Tim Ingold, por outro lado, seguindo os passos de James Cibson (1979) e Gregory Bateson (1976), considera que a percepção do ambiente não é uma atividade exclusiva da mente, mas sim um processo contínuo que envolve todo o corpo na medida em que a pessoa se movimenta, de maneira direta, ao redor do ambiente, explorando-o completamente (Ingold, 2000). A mente está, portanto, menos dentro da cabeça e mais no mundo ou, nos termos de Bateson (1976), a mente não se limita à pele, mas ao contrário, se expande pelos múltiplos caminhos da participação e percepção sensorial, sendo imanente ao sistema total de relações entre organismo e ambiente onde nós, humanos, estamos envolvidos. De maneira semelhante, o corpo não é uma entidade estática, um invólucro independente, mas sim um movimento constante que experimenta um contínuo crescimento em função de suas múltiplas relações ambientais (Ingold, 2008: 25). Sendo assim, mente e corpo ou, de igual modo, cultura e natureza, não são duas dimensões separadas, mas duas maneiras de evidenciar um mesmo processo: a atividade, o movimento, os caminhos seguidos ou experimentados pela pessoa-organismo em seu ambiente. Movimentar é, portanto, uma forma de perceber, conhecer e interagir com o mundo. Movimentar é estar vivo, e viver é um processo de desenvolvimento.

\section{A UNIDADE SAGRADA}

Gregory Bateson, assim como Ingold, também parece estar à procura da vida. Mais exatamente, ele está em busca do "padrão que liga todas as criaturas vivas". O padrão que liga, outro título possível para o seu livro Mente e Natureza, afirma: "Que padrão relaciona o caranguejo à lagosta, a orquídea à prímula e todos os quatro a mim? E eu a você? E nós seis à ameba em uma direção e ao esquizofrênico retraído em outra?" (Bateson, 1986: 16). Perceber tal padrão demandaria uma sensibilidade estética e uma compreensão para a natureza harmônica ${ }^{4}$ das coisas vivas, ou seja, uma atenção para as formas, os contornos, as repetições, as relações entre as partes que compõem e caracterizam as coisas vivas. A anatomia do corpo humano, bem como de todos os seres vivos, é rítmica e repetitiva. "O úmero no antebraço corresponde ao fêmur na coxa, o rádio-cúbito corresponde à tíbia-perônio; os ossos no pulso correspondem aos do tarso no pé; os dedos da mão correspondem aos dedos do pé" (Bateson, 1986: 16-17). Tais conexões, comparações e repetições são denominadas pelos biólogos de homologia seriada e a necessidade de produzir uma reflexão e uma consequente generalização sobre tais relações e conexões é o que permitirá alcançar (e pensar sobre) o padrão
4 Harmonia, nesse caso refere-se muito mais a um sentido musical (ou estético) atribuído à palavra -isto é, à combinação de elementos ou sons que produzem uma determinada relação ou sensação estética - do que a uma ideia que pressuponha qualquer ausência de conflito ou tensão. Dito de outra forma, tanto uma relação de cooperação quanto de competição pode ser caracterizada como "harmônica" visto que a ênfase, segundo esse entendimento, estará centrada na sensibilidade estética proporcionada por um olhar atento à relação entre as coisas e não às coisas em si. 
que liga, o padrão dos padrões, o metapadrão $0^{5}$.

Infelizmente, aponta Bateson (1986: 21), nós ocidentais fomos educados pelas nossas instituições oficiais de ensino a imaginar os padrões como estáveis, invariáveis, inflexíveis, quando o correto seria imaginá-los como um imbricado processo de interações e transformações, como uma "dança" de partes que interagem de maneira criativa. As coisas vivas apresentam tais padrões e formas harmoniosas (visualizadas, por exemplo, em suas simetrias ou em suas formas espirais) porque são decorrentes do processo de crescimento e transformação que perpassa todas as criaturas vivas. Tal processo evolutivo ou de crescimento compõe o que Bateson chama de história. As histórias são as sequências de formação e transformação dos seres, suas embriologias e filogenias, que dependem de um contexto para existirem e significarem. O contexto é, nesse sentido, algo essencial para o desenrolar de tais histórias, acontecimentos e processos de crescimento e evolução ${ }^{6}$.

Se o contexto determina o significado das coisas, logo a atenção deve estar sempre para a relação entre as coisas e suas partes e não propriamente nas coisas em si. O interesse de Bateson está na ação e na relação entre as coisas e não em seus atributos. Como percebido por Johann Goethe, "um caule é o que carrega folhas; uma folha é o que tem um broto num canto; um caule é o que foi uma vez um broto naquela posição" (apud Bateson, 1986: 25). No entanto, diz Bateson, a maioria de nós, ocidentais, aprendeu a ver e definir as coisas pelo que elas são em si mesmas e não por meio de suas relações com todas as outras coisas. Por exemplo, aprendemos nas escolas que uma mão tem cinco dedos quando o correto seria afirmar que ela contém quatro relações entre os dedos (Bateson, 2006: 381). Agindo dessa maneira nós perdemos o sentido de totalidade e de unidade estética e sagrada presente entre as coisas vivas e também entre as suas partes. Bateson, então, sugere que o olhar para as relações, e não para as coisas em si, faz com que tais coisas se tornem muito mais belas e sagradas segundo nossa própria percepção. Ao contrário, uma visão materialista e mecanicista do mundo tende a ignorar esses circuitos e conexões apostando numa clara separação ou divisão entre coisas que, todavia, não deveriam ser pensadas como estando separadas ou divididas. É contra esse tipo de visão que Bateson irá propor uma nova epistemologia, ou seja, uma nova maneira de pensar, sentir, perceber e conhecer o mundo vivo que habitamos.

O problema da visão materialista do mundo, diz Bateson, é que ela está ancorada nos pressupostos dualistas estabelecidos por Descartes no século XVII, tendo como base, sobretudo, a divisão entre espírito e matéria. Descartes, na visão de Bateson, teria sepultado a possibilidade de uma percepção monista do mundo que esteve presente, ao menos, desde a antiga Crécia (Bateson e Bateson, 1987: 25). Na percepção monista, mente e natureza, espírito e matéria,
5 A busca por padrões poderia soar um tanto estranha a alguém como Tim Ingold, para quem a antropologia esteve excessivamente preocupada em estabelecer modelos, construir estruturas e etc., deixando de lado aquilo que, a seu ver, era o essencial: a vida e suas infinitas possibilidades. Em sua visão (Ingold, 2011), tais modelos contribuiriam negativamente para o "congelamento" da vida, impedindo-a de se movimentar livremente e improvisar caminhos ao longo de suas linhas e tessituras. Todavia, a ideia de padrão conforme imaginada por Gregory Bateson não pretende, de modo algum, congelar ou estabilizar a vida, interrompendo o seu livre caminhar. Ao contrário, ela segue a vida em busca de suas ligações e relações, seus movimentos e improvisos que produzem uma diferença. Tratase, em suma, de um padrão que está fundamentalmente à procura da vida.

6 Esse borrar da fronteira entre história e evolução também é algo que caracteriza o pensamento de Tim Ingold. Para ele, a história é uma continuação do processo evolucionário sendo, portanto, constitutiva de todos os seres humanos e não-humanos que habitam o mundo. São os rastros, as trilhas, os caminhos construídos e deixados pelos organismos ao longo de uma vida. Tal entendimento da história implicará na dissolução "de uma só vez da dicotomia entre sociedade e natureza, e no reconhecimento que os processos pelos quais as gerações humanas moldam as condições de vida de seus sucessores estão em continuidade com aqueles que ocorrem em todo o mundo orgânico" (Ingold, 2006: 21) 
formam uma necessária unidade, de modo que inexistiria, tal como pressupõe o dualismo cartesiano, uma mente separada de um corpo ou mesmo um Deus separado (transcendente) de sua criação. Trata-se da ideia de um "mundo integrado", bastante presente, inclusive, na filosofia romântica alemã dos séculos XVIII eXIX (Cusdorf, 1984). Tal ideia, no entanto, foi aos poucos abandonada pela explicação científica racionalista, culminando na total separação entre mente e matéria e na ausência de qualquer formulação que levasse em conta as possíveis relações entre ambas. O ápice dessa percepção foi no século XIX, especialmente a partir da publicação de A origem das espécies (1859), de Charles Darwin, quando tentou-se excluir definitivamente a mente como um "princípio explanatório" da história natural. Contudo, Bateson (1986) lembra que, 50 anos antes, Jean-Baptiste de Lamarck, em sua Philosophie Zoologique (1809), fazia um interessante uso da ideia de mente como explicação para o processo de transformação e evolução dos seres vivos. Invertendo a "grande cadeia da existência" apregoada por Santo Agostinho, na qual a "Mente Suprema" estaria no topo da escala (sendo sucedida pelos anjos, homens, macacos e demais seres), Lamarck sugere que a mente é imanente (e não transcendente) às criaturas vivas, podendo determinar suas transformações. Desse modo, segue argumentando Bateson, ele

escapou da premissa direcional negativa de que o perfeito deve sempre preceder o imperfeito. Ele propôs então uma teoria do "transformismo" (que chamaríamos de evolução) que começou com o infusório (protozoário) e subiu até o homem e a mulher" (1986: 27).

Todavia, o interesse de Lamarck pela mente será deixado de lado pelas teorias biológicas desenvolvidas nas décadas seguintes para ser retomado somente após a Segunda Guerra Mundial, com o advento da cibernética e da teoria dos sistemas e da informação (Bateson, 1976). Tais teorias, além de terem deslocado a grande e persistente dicotomia cartesiana, contribuíram para oferecer outro entendimento do mundo a partir de suas ligações ou conexões com seus aspectos mentais.

De maneira concomitante, na tentativa de estabelecer uma epistemologia e uma linguagem mais adequada para pensar o mundo que as proposições cartesianas, Bateson recupera as ideias de Pleroma e Creatura trazidas, do gnosticismo, por Carl Jung em seu Septem Sermones ad Mortuos. O primeiro termo consistiria no mundo da matéria inanimada, não-vivente, descrito pelas leis da física e da química, cujo os acontecimentos são causados por forças e impactos, mas que em si mesmo não contém ou fornece distinções ou descrições sobre o mundo. Nos termos de Bateson, trata-se de um mundo no qual não existem diferenças, ideias, informações ou qualquer caraterística predeterminada. "A 
pedra é afetada por 'forças' ou 'impactos', mas não por diferenças. Eu posso descrever a pedra, mas a pedra não pode descrever nada. (...) A pedra não usa nem contém nenhuma informação" (Bateson e Bateson, 1987: 30). A Creatura, por sua vez, seria o mundo da explicação e representação de fenômenos governados por diferenças, distinções e informações. Trata-se do mundo da linguagem e das diferenças que permitem descrever ou traduzir as regularidades imanentes ao Pleroma. Este, porém, apesar de existente, continua sendo em si mesmo inacessível. Nesse sentido, o conhecimento (virtual) sobre o Pleroma só seria possível de se realizar (ou de se atualizar) por meio da Creatura. Em que pese a aparente dualidade existente no modo como tais categorias são apresentadas, Bateson afirma que não podemos tratar o Pleroma e a Creatura como dois níveis ou dimensões separadas, mas sim combinadas, visto que tudo o que pertence à Creatura existe dentro do Pleroma, e este último depende daquela para ser de alguma maneira acessado. Assim,

Creatura e Pleroma não são, como "o espírito" e "a matéria" de Descartes, substância separadas, pois os processos mentais exigem disposições da matéria para acontecer, exigem zonas nas quais o Pleroma está caracterizado pela organização que o faz suscetível de ser afetado pela informação assim como pelos eventos físicos (Bateson e Bateson, 1989: 31).

Em Mente e Natureza, Bateson (1986) apresenta a ideia de Creatura como um possível sinônimo para mundo vivo, do qual todos nós fazemos parte 7 . Ele também relaciona Creatura à sua ideia de mente ou processo mental, a qual abordaremos a seguir. Antes disso, contudo, vale a pena destacar rapidamente a relação que o autor estabelece entre Creatura e Pleroma, mapa e território.

"O mapa não é território", afirmou o filósofo e cientista polonês Alfred Korzybski (1879-1950), de modo que do território, o que pode ser delineado como mapa é a informação, a notícia da diferença. Informação, para Bateson, é $a$ diferença que faz uma diferença, e diferença é tudo aquilo que interrompe a uniformidade e continuidade do território, seja, por exemplo, em sua altura, superfície ou vegetação, seja na estrutura de sua população. Logo, o que o mapa captura do território é na verdade uma infinidade de diferenças; diferenças estas que, no momento em que as selecionamos e estabelecemos relações, fornecerão um conjunto de informações. Como vimos, para Bateson, tal reconhecimento da diferença pertence ao domínio da Creatura, do processo mental, distinto das variações e sequências físicas ou mecanicistas, mas não separado substancialmente das mesmas. Entende-se, nesse sentido, que no Pleroma não há mapas, pois estes só existem de fato na Creatura, o que implica a impossibilidade de termos um acesso direto ou imediato à "coisa em si". Acreditar que seja possível
7 Em seu esforço de aproximar organismos humanos e não-humanos, Ingold (2000: 16) questiona não só a manutenção dessa dualidade como também a própria explicação que Bateson fornece a ela. Afinal, para Ingold, a pedra possui um mundo, uma perspectiva sobre ele e, além do mais, é perfeitamente capaz de agir e se relacionar com os outros organismos que a cercam. A pedra, portanto, está viva, tem um ponto de vista e é constantemente atravessada pelo fluxo de materiais com os quais interage (Ingold, 2011). Assim, em sua visão, não faria sentido essa distinção entre Pleroma e Creatura ou, se não quisermos abrir mão dessa linguagem, para ele, todos os organismos constituiriam, em última instância, um único mundo (vivo) da Creatura. 
ter um conhecimento direto sobre o mundo é confundir o mapa com território supondo que "as regras para traçar mapas são imanentes à natureza daquilo que se representa no mapa" (Bateson e Bateson, 1987: 33). O território nunca aparecerá em absoluto na medida em que a própria construção do mapa cria as características do território. O processo mental sempre o filtrará, de modo que o nosso mundo será sempre formado por mapas de mapas de mapas que correspondem a transformações de diferenças (Bateson, 1976: 309-311).

Quem realiza o processamento das informações e a codificação das diferenças obtidas é a mente. Esta, contudo, ultrapassa os limites da pele (e do cérebro) na medida em que o mundo físico externo não pode ser pensado como algo separado do mundo mental interno. As mensagens transmitidas fora da pele devem fazer parte do sistema mental e, para ilustrar tal argumento, Bateson (1976: 312; 2006: 223) apresenta o caso de um homem que utiliza um machado para derrubar uma árvore. Ele chama a atenção para o movimento que o machado faz em direção à árvore e as incisões que realiza e criam diferenças. Assim, diz ele, se quisermos explicar este conjunto de fenômenos, devemos lidar com as diferenças geradas na superfície da árvore, as diferenças na retina do homem, de seu sistema nervoso central e de seus músculos, bem como as diferenças no modo como o machado se move no ar. Nesse sentido, a explicação deve abarcar todos esses circuitos e, se quisermos compreender o comportamento humano, devemos estar atentos e dar conta da totalidade desses circuitos. Nisso consiste, segundo Bateson (2006), o pensamento ou sistema cibernético. Para delinear tal sistema devemos "traçar uma linha fronteiriça sem cortar nenhuma das vias e sem deixar coisas por explicar". Se, por exemplo, desejamos explicar o comportamento e a locomoção de um cego, devemos levar em conta a rua, a bengala e o homem, não importando o ponto em que se comece a analisar a relação, pois o foco está justamente na relação e não nos elementos em si. Desse modo, voltando ao exemplo anterior, e pensando no fato de que a mente não está limitada pela superfície da pele, o sistema cibernético produzido no ato de derrubar a árvore não é ou não define a ideia de mente no homem que derruba a árvore, ou seja, não está na coisa em si, mas sim numa mente que compreende (ou apreende) as diferenças relacionando as características da árvore, o movimento do machado, o comportamento do homem e etc., todos juntos compondo um circuito completo (ou ecológico) de interações. Não podemos, portanto, localizar a mente em um único lugar (por exemplo, no corpo humano isolado de seu ambiente) ou em um só ponto do circuito, pois se trata de um sistema aberto de múltiplas conexões e interações, de inúmeros caminhos e transformações. A mente, nesse sentido, ao se constituir no ambiente, "deixa de ser compreendida como uma máquina produtora de representações e se torna fundamentalmente uma mediação relacional com o mundo" (Steil e Carvalho, 2014: 171). 
Disso deriva a perspectiva cibernética de pensar o mundo de uma maneira interligada, dinâmica e ecológica, entendendo-o como um sistema integrado e autorregulado de processos e conexões. Por outro lado, a falta de uma perspectiva sistêmica sobre o mundo ocasionada, por exemplo, pela separação entre mente e matéria, razão e emoção ou entre ser e ambiente, resulta numa percepção dominada ou orientada pela ideia de um propósito consciente (Bateson, 1976). Nossa consciência tende a operar por meio de propósitos que selecionam acontecimentos, enfocam partes, elaboram recortes, criam atalhos que procuram chegar aonde queremos pelo caminho mais linear possível, sem se preocupar em pensar no sistema como um todo. O problema, no entanto, das ações baseadas em um propósito consciente é tomar a parte pelo todo, ou seja, achar que o que é visto pela consciência tem o caráter da mente como um todo. $\mathrm{A}$ consciência é, na realidade, uma parcela menor e limitada de uma mente maior, é uma tela que registra apenas uma parte da mente, fornecendo uma mostra sistemática de todo o restante (Bateson, 1976: 295). Trata-se, sem dúvida, de um conhecimento importante e eficaz - Bateson traz como exemplo os esforços da medicina em suas pesquisas sobre medicamentos derivados justamente desse tipo de pensamento voltado para propósitos específicos - que, porém, por não levar em conta o funcionamento de um organismo ou de uma vida em sua totalidade, desconhecendo, inclusive, seus mecanismos internos de controle e regulação, acaba por comprometer o equilíbrio do sistema total, afetando sua ecologia e produzindo mudanças muitas vezes irreversíveis. Além disso, lembra Bateson (1976: 297), o avanço tecnológico produzido pelo conhecimento científico voltado exclusivamente para propósitos conscientes faz dele uma perigosa ameaça para a perda definitiva do equilíbrio de um sistema (seja o nosso próprio corpo, a nossa sociedade ou mesmo o mundo biológico). Nos termos do físico austríaco Fritjof Capra, o pensamento abstrato baseado na ideia de um propósito consciente

nos tem levado a tratar o meio ambiente natural - a teia da vida -como se ele consistisse em partes separadas, a serem exploradas comercialmente, em benefício próprio, por diferentes grupos. Além disso, estendemos essa visão fragmentada à nossa sociedade humana, dividindo-a em outras tantas nações, raças, grupos religiosos e políticos. A crença segundo a qual todos esses fragmentos - em nós mesmos, no nosso meio ambiente e na nossa sociedade - são realmente separados alienou-nos da natureza e de nossos companheiros humanos, e, dessa maneira, nos diminuiu. Para recuperar nossa plena humanidade, temos de recuperar nossa experiência de conexidade com toda a teia da vida. Essa reconexão, ou religação, religio em latim, é a própria essência do alicerçamento espiritual da ecologia profunda (1996: 217). 
Assim, contra essa lógica fragmentária e potencialmente destrutiva ${ }^{8}$, Bateson propõe uma nova forma de pensar, uma outra epistemologia, envolvida em mais humildade e sabedoria e, porque não, menos consciente e propositiva; uma epistemologia em que a "mão esquerda" nem sempre saiba o que a "mão direita" anda fazendo9. Agir com sabedoria significa estar atento ao sistema interativo como um todo, atento a suas relações e transformações, reconhecendo a dimensão sistêmica dos organismos, da vida e do mundo (Bateson, 1976: 296). Tais dimensões ou forças sistêmicas podem ser chamadas de mente ou, simplesmente, Deus. Agir com mais humildade e menos arrogância, afirma Bateson, é perceber que nós fazemos parte desse sistema maior, que nós somos parte de Deus, e que não podemos controlá-lo. "Não vivemos em um universo que permite um simples controle linear. A vida não é assim" (1976: 299). E mesmo dentro do ser humano individual o controle é limitado. Podemos aprender uma série de coisas abstratas, "mas de nenhuma maneira somos os capitães de nossa alma" (1976: 300).

Trata-se, nesse sentido, de uma perspectiva que seja capaz de perceber a unidade das coisas, o indivíduo em sua totalidade, o ser em seu ambiente, tal como fazem, na visão de Bateson, a arte e a religião. Tanto uma como a outra percebem o mundo de uma maneira unificada ou holística, e não dualista, referem-se ao todo, e não às partes (2006:378). Ambas, a estética e a sacralidade, estão mais atentas às relações que às coisas e seus atributos. Tanto a arte como a religião dão grande valor aos silêncios, às pausas, à contemplação, à não-verbalização e à inconsciência, pois sabem que comunicar uma ideia a alguém implica inevitavelmente transformar a natureza daquela ideia (e daquele alguém). Finalmente, as duas, de diferentes maneiras, potencializam experiências criativas nas quais a consciência desempenha um papel apenas secundário.

Bateson compreende a religião ou, mais exatamente, o sagrado como uma síntese fantástica, uma ponte, que conecta todas as coisas, produzindo um modo de dar um sentido à vida. Em seu entendimento, tal dimensão tem sido cada vez mais maltratada pela sociedade ocidental que tem feito uso dessa ponte sagrada com o único propósito de "vender coisas", perdendo assim o sentido de unidade estética e sagrada do mundo (2006: 340). Trata-se de um engano epistemológico que ainda pode ser corrigido, pois "ainda existe pelo menos um impulso no coração humano no sentido de unir e dessa forma santificar o completo mundo natural a que pertencemos" (1986: 26).

Um modo de conhecimento que atribui um caráter sagrado à organização do mundo biológico pode ser mais preciso e mais apropriado para tomar decisões que um modo de pensar baseado exclusivamente em propósitos conscientes. E apesar de relacioná-lo com a parte do cérebro ligada à poesia, aos sonhos e às emoções, Bateson (1987: 9) sugere que, na verdade, o sagrado é a união e não o produto da divisão de duas dimensões ou de dois modos de conhecimento, um
8 Algo que, num certo sentido, corresponde à diferenciação que Ingold (2012c) estabelece entre $e x-$ habitantes e in-habitantes, isto é, entre aqueles que ideológica e ontologicamente se consideram fora ou separados do ambiente que habitam, o que supostamente lhes daria o direito de explorá-lo, utilizá-lo, fragmentá-lo e até destruí-lo, e aqueles que, por outro lado, se percebem enquanto partes inerentes ou inseparáveis do mundo da vida, que estão (e são) organicamente dentro do mundo.

9 Tal argumento, inspirado numa passagem bíblica, foi desenvolvido por Bateson (1987) em um dos capítulos do livro Angels Fear: Towards an Epistemology of the Sacred, quando sugeriu que o processo de tornar consciente, de controlar ou de comunicar (propositadamente) uma determinada ideia nem sempre se faz necessário se o que está em jogo é, sobretudo, o desenvolvimento de experiências baseadas numa percepção sistêmica ou sagrada da vida e do ambiente. 
ligado à prosa e à lógica racional, e outro ligado à poesia e às conexões sistêmicas. O sagrado é, portanto, a dimensão integradora da experiência humana. É aquilo que sustenta a vida (Bateson, 2006: 343). É, enfim, um modo de ser que estabelece conexões e não divisões, estando sensível ao padrão que liga e à beleza da unidade.

\section{EM BUSCA DE UMA PERCEPÇÃO SAGRADA DO AMBIENTE}

Como já apontado por alguns autores, as conexões entre Bateson e Ingold, ao menos em partes específicas de suas obras, são bem evidentes (Velho, 2001; Bonet, 2014; Steil e Carvalho, 2014) ${ }^{10}$. Vimos que ambos fazem críticas ao dual ismo cartesiano e suas consequentes divisões. Para um, diríamos que a separação mente/matéria retira a vida das coisas, transformando-as em objetos sem movimento, desconectados de suas teias, de seus ambientes (Ingold, 2012b). Para outro, tal divisão metafísica é um engano epistemológico, um erro que precisa ser corrigido se quisermos produzir uma compreensão ou uma leitura mais adequada do mundo que habitamos (Bateson, 1986). Uma compreensão que esteja mais atenta às relações entre as coisas que às coisas em si. Assim, ambos compartilham de uma percepção monista do mundo apoiados na ideia de que tais divisões não estão nele e, mais que isso, são prejudiciais a ele na medida em que interrompem seus fluxos e movimentos. A mente ultrapassa os limites da pele, conectando o organismo ao ambiente que o envolve (e a todos os seres que nele habitam). Trata-se, nos termos de Bateson (1976), não só do corpo-no-ambiente, mas também da célula-no-corpo, do DNA-na-célula ou, segundo Ingold (2011), do pássaro-no-ar, do peixe-na-água, da aranha-na-teia e assim por diante, pois não existe ser sem ambiente e ambiente sem ser. A relação ser-no-ambiente (o Daisen heideggeriano) é percebida por tais autores como um processo de crescimento ou de desenvolvimento no qual se evidencia a constante transformação das coisas ou organismos que formam um mundo vivo autorregulado. Tais processos podem ser entendidos como histórias ou caminhos percorridos, que compõem malhas ou itinerações (Ingold, 2012b).

A autorregulação que caracteriza esse mundo vivo foi algo notado não só por Bateson e Ingold, mas também por outros pensadores sistêmicos, antes mesmo da cibernética. Baruch Spinoza (2007 [1677]), com a ideia de conatus, talvez tenha sido um dos primeiros a perceber a capacidade ou o impulso natural dos organismos para persistirem em seus próprios seres. Os organismos são, portanto, sistemas de autorrealização. Os genes, nesse mesmo sentido, são sistemas automantenedores; os ecossistemas são autorregulados; o universo é considerado um sistema autorrealizado. Tal autorrealização das coisas é também um ato de autotransformação (Milton, 2002: 85), algo que certamente se aproxima das ideias ingol-
10 A influência de Bateson à obra de Ingold certamente não se limita apenas às ideias apresentadas em Steps to Ecology of Mind (Bateson, 1973) ou em Mind and Nature (Bateson, 1980), trabalhos constantemente mencionados pelo autor em diferentes momentos de sua trajetória intelectual (Ingold, 2000, $2008,2011,2013)$. Mais que isso, Ingold reconhece que grande parte de sua visão de mundo ("ecológica") e de ciência ("antidisciplinar") se deve a uma inspiração batesoniana. Não por acaso, ele afirmou, em entrevista relativamente recente, que Batesonjuntamente com Hallowell, Gibson, Bergson, MerleauPonty, Deleuze e Guattari - foi um dos autores que mais influenciou o seu trabalho. Eainda disse, na mesma entrevista, que o pensamento de Bateson "está no cerne do que eu [Tim Ingold] estou tentando fazer agora" (Ingold apud Bonet et al., 2014: 311). 
dianas e batesonianas de pensar a vida como um fluxo criativo (ou generativo), de processos de desenvolvimento e de sistemas autocorretivos.

A despeito dessas semelhanças e continuidades, Ingold, até onde sabemos, ainda não se debruçou diretamente sobre o conceito de sagrado desenvolvido por Bateson, algo que, no entanto, não nos impossibilita que estabeleçamos certas aproximações, especialmente se levarmos em conta o desejo do próprio Ingold de elaborar uma antropologia com a religião (ou com o sagrado) e não sobre a religião (ou sobre o sagrado), de maneira análoga, portanto, aos paralelos realizados pelo mesmo autor entre a antropologia e a arte (Ingold apud Bonet et al, 2014; Ingold, 2012a). Nessa direção, recuperando a ideia de sagrado batesoniana para tentar compreender o que leva as pessoas a se interessarem, valorizarem e respeitarem a natureza, Kay Milton, antropóloga britânica, colega e interlocutora de Tim Ingold, em sua obra Loving Nature: Towards an Ecology of Emotion (Milton, 2002), procura enfatizar o sentido de totalidade ou de unidade presente numa percepção sagrada do ambiente que tende a valorizar as relações e conexões entre as coisas. Nesse aspecto, a análise de Bateson é fundamental para perceber a dimensão não-comunicacional da sacralidade, dependendo que certas coisas permaneçam escondidas, silenciadas e distanciadas de um pensamento racional, baseado na ideia de um propósito consciente, e mais próximas, por outro lado, das experiências proporcionadas pela poesia, pelo transe ou pelo sonho.

Milton (2002:104) chama a atenção para o fato de que em muitas culturas não-ocidentais as emoções e os sentimentos são assumidos como tendo um efeito direto no mundo para além do corpo ou da mente que experimentou tais sensações. Nesse sentido, as emoções são capazes de fazer as coisas acontecerem. A compreensão de Bateson sobre o sagrado ou sobre como a sacralidade motiva as pessoas a fazerem coisas como, por exemplo, proteger e cultuar a natureza, ajuda a entender melhor essa capacidade das emoções para fazer as coisas acontecerem. Para Bateson (2006: 343), sagradoé, também, aquilo que mais importa a uma pessoa, aquilo que lhe tem mais valor, aquilo a que uma pessoa se dedica com muito empenho e afetividade (seja na arte, na ciência, na religião ou em qualquer outra área). O entendimento do que é sagrado depende, desse modo, do quão profundamente uma pessoa deposita sua atenção e sua emoção sobre uma determinada coisa ou projeto. Assim, ao atribuirmos um sentido especial a alguma coisa, nós tornamos aquela coisa sagrada, ou seja, nós a atribuímos um valor justamente a partir das emoções e sentimentos que carregamos (Milton, 2002: 105).

O que significa, portanto, pensar e sentir o mundo de uma maneira sagrada, ou seja, estabelecer não uma percepção sobre o sagrado (substantivado, objetificado e preexistente), mas sim uma percepção (con)sagrada do ambiente? 
A partir do que foi exposto até agora, e inspirado em tais autores, diríamos que perceber o universo, as coisas, os seres e a si mesmo de uma maneira sagrada significa estar atento às continuidades, às conexões, aos fluxos que percorrem, unificam e atravessam todo o ambiente. Significa estabelecer conexões ou (re) ligações entre diferentes planos ou dimensões e entre os próprios seres humanos (e não-humanos). Pensar com sagrado ou sagradamente significa (re) ver ou (re)ler o ambiente de uma forma mais atenta, traçando continuidades simétricas entre todas as coisas encontradas no mundo vivido e, ao mesmo tempo, percebendo suas diferenças e variações. Dito de outra maneira, perceber o ambiente, as coisas ou as situações da vida cotidiana de uma forma sagrada, implica um modo específico de ver e agir sobre o mundo. Nesse sentido, o sagrado refere-se mais a um modo singular de ver (ou ler) as coisas que propriamente às coisas em si; refere-se, enfim, a um modo de ver que procura ir além do que comumente se vê.

A ideia de ler ou reler o ambiente de uma maneira específica, mais atenta, se relaciona a um dos possíveis sentidos etimológicos presentes na palavra religião (cf. Azevedo, 2010). De raiz latina, o substantivo religio seria originalmente derivado do verbo relegere que significaria ler novamente, com cuidado, mais devagar, procurando perceber aquilo que não fora percebido numa primeira leitura, num primeiro ol har desatento. Significaria, nesse sentido, ler com uma atenção voltada para a relação entre coisas, entre as palavras, entre as linhas, e não às coisas em si. E será essa ênfase à atenção e à relação que possivelmente dará margem a uma outra interpretação para origem do mesmo vocábulo. Trata-se de religare, definido como religar, unir, juntar algo que havia sido perdido ou esquecido (no caso, o vínculo que liga a humanidade à divindade). Assim, tanto num caso, quanto noutro, o que está em jogo é uma espécie de atenção à relação entre seres, coisas, palavras, dimensões e etc., ou seja, uma educação do olhar que estimula uma outra forma de perceber (ou "reler") essas ligações que existem, mas que por alguma razão (ou por algum "propósito") foram esquecidas ou negligenciadas numa primeira leitura.

Aliás, o contrário da religião ou do relegere, lembra Ingold, "não é o ateísmo, não é a falta de crença, e, sim, a negligência, negligere, não prestar atenção ao mundo, não ser aconselhado pelo mundo, não estar preparado para aprender com as coisas que estão à nossa volta" (ênfases minhas, apud Bonet et al, 2014: 307). Assim, acrescenta o autor, a religião ou o sagrado envolveria, em última instância, uma questão de "comprometimento ontológico", um modo diferenciado de ser, perceber, conhecer e se relacionar com tudo aquilo que nos cerca.

Em um sentido epistemológico ou "epistemontológico" (visto que, para tais autores, ser e conhecer correspondem a um único processo), a ideia de uma percepção sagrada do ambiente, tal como imaginamos, apostaria na potencialidade do conceito de sagrado desenvolvido por Bateson - ou seja, no sagrado pensado 
enquanto união e comunhão e não como separação ou interdição - para dissolver as barreiras criadas por um modo hegemônico de conhecer e fazer ciência, denunciado por Ingold (2011), que se estrutura em divisões, especialidades ou disciplinas que fragmentam a vida, o corpo, o ambiente, os seres, as coisas, enfim, que segmentam a realidade em partes assimétricas, "objetificadas" e desconectadas de uma totalidade. Tal percepção sagrada do ambiente baseia-se, portanto, em outros modos de conhecer, em outras epistemologias que foram, há muito tempo, exiladas do "território da verdade" definido pela ciência dominante (Steil e Carvalho, 2014). São visões de mundo ecológicas capazes de borrar as fronteiras entre os saberes, apostando na antidisciplinaridade e questionando os limites de suas próprias práticas. São "estilos de pensamento" (Fleck, 2010) que mantêm estreitas relações não só com a filosofia, mas também com a arte e a religião"1 justamente porque querem trazer a vida ou o princípio vital para o centro de suas investigações. Aqui ressoa uma inspiração vitalista e romântica que atravessa grande parte dessas epistemologias ecológicas (Steil e Carvalho, 2014). Ressoa, também, a liberdade e criatividade exercida por aqueles que se encontram nas margens dos saberes e se interessam pelas misturas ou por aquilo que escapa dos modelos rígidos e fragmentados de ciência, filosofia, arte, religião... Assim, "em vez de superfícies territoriais segmentadas em domínios, ou campos de estudos, temos algo mais semelhante a cordas, trançadas com os correspondentes fios ou linhas de interesse" (Ingold, 2013: 12).

\section{PALAVRAS FINAIS}

Para encerrar, gostaria de resgatar um aspecto ou uma linha desenvolvida por Ingold e que pode se constituir num interessante elemento para a compreensão e o desenvolvimento de uma percepção sagrada do ambiente, tal como apresentada nesse ensaio. Trata-se da crítica à separação entre fato e imaginação, ou sonho e realidade, provocada por certa leitura do mundo, por certo modo desatento de perceber tudo aquilo que nos envolve e afeta.

"Não se preocupe, foi só um sonho". É isso que nós, modernos, dizemos àqueles que, assustados pelas experiências vivenciadas no momento em que dormiam, simplesmente acordam sem entender direito onde estão ou o que se passou com eles. Afinal, somos ensinados, desde muito cedo, a desconfiar dos nossos sonhos, das nossas sensações, "a confiar mais no intelecto do que na intuição e a considerar a imaginação como uma fuga da vida real e não como seu impulso". Assim, ao dizer que tudo não passou de um sonho, restauramos a fronteira entre o fato (ou a realidade) e a imaginação (ou a irrealidade), pois "quase que por definição o imaginário é irreal: é a nossa palavra para aquilo que não existe" (Ingold, 2012d: 17). No entanto, nós nem sempre fomos modernos (ou, talvez, diriam alguns,
11 Eque podem resultar numa "teologia da vida", se quisermos utilizar a expressão sugerida por Otávio Velho para pensar a antropologia de Tim Ingold (cf. Steil e Carvalho, 2013). 
nós nunca tenhamos sido). Na Idade Média, lembra Ingold, as coisas eram bem diferentes; a imaginação não ocupava um domínio separado da vida real; dragões (e outros seres "mais-que-humanos") existiam e nos aterrorizavam não como um elemento pertencente ao mundo natural, mas sim como um fenômeno da experiência humana que é tão real quanto a expressão de quem sofre ou sente medo (Ingold, 2012d: 19). Ver esses seres e ouvir o que eles têm a dizer para nós, humanos, envolve uma outra maneira de perceber e imaginar o mundo; envolve, portanto, uma outra maneira de ser e saber. Um saber que depende do ver, um saber ver. Assim, por exemplo, um monge beneditino, atormentado por dúvidas e inseguranças em relação ao caminho que deveria seguir, só foi capaz de ver o dragão que há tempos o acompanhava quando deixou de olhar com os sentidos físicos e adotou uma outra percepção, uma outra maneira de ver (além). Para ele, e também para os povos "não-modernos", o dragão e todos os seres que habitam o universo não são recursos analógicos ou metáforas que representam alguma coisa, mas sim interlocutores vitais. Trata-se de um universo poliglota: "um híbrido de vozes pelas quais diversos seres, em suas línguas diferentes, enunciam sua presença, são sentidos e fazem seu efeito". E para sobreviver, ou melhor, para saber viver, devemos aprender a nos "sintonizar com essas vozes, ouvir e reagir ao que elas Ihe dizem" (Ingold, 2012d: 21). Tal sintonia envolve uma forma de aprendizado, uma educação da atenção (Ingold, 2000, 2015), que implica o estabelecimento de uma relação de comunhão, afeto e empatia com esses outros seres. Implica, portanto, um movimento de abertura de si em direção ao ambiente.

$\mathrm{Na}$ Idade Média, especialmente nos contextos religiosos, o ato de ler pressupunha necessariamente uma leitura em voz alta, atenta às linhas, ou mais exatamente, às entrelinhas, isto é, ao conjunto do que é dito e ao sentido implícito contido no texto. Tratava-se de estar atento às "vozes das páginas", procurando ouvir, imaginar e se aconsel har com os diferentes personagens ou as diferentes criaturas encontradas no decorrer da leitura. Ler, no sentido medieval, era comparado ao trabalho de um caçador que, em sua caminhada, ouvia as "vozes da natureza" para tentar encontrar aquilo buscava. O exercício da leitura, nesse sentido, também envolveria uma caminhada, um movimento em direção a algum lugar ou a alguma experiência (nesse caso, uma experiência sagrada). No entanto, aponta Ingold, a reforma protestante e, posteriormente, o pensamento científico (apoiado, em termos gerais, na ideia de propósito consciente e na distinção entre fato e imaginação) silenciaram o texto no intuito de encontrar o sentido literal ou a verdade que ele supostamente carregava. Mais que isso, a ciência moderna, no seu gigantesco projeto de classificação ou taxonomização da realidade, acabou por silenciar a própria natureza, transformada agora em um objeto não só de sua atenção, mas principalmente de seu controle. Preocupada 
em controlar e não mais em dialogar com a natureza, a ciência expulsou de sua taxonomia tudo aquilo que poderia escapar de seus critérios de realidade (os dragões, por exemplo). Assim, para que nada pudesse comprometer ou interferir na objetividade de seus resultados, a ciência silenciou e distanciou-se do mundo (e da vida), deixando de ouvir suas vozes, deixando de conversar com os dragões que a acompanhavam (e ainda acompanham), deixando, enfim, de dar uma importância sagrada (Bateson, 2006) a tudo aquilo que podemos sentir e perceber em um ambiente.

Ao propor que caminhemos com os nossos dragões, Ingold sugere que aprendamos a lidar com a imaginação de uma maneira mais adequada, mais equilibrada e até mais religiosa, diz ele (2012d: 28), sem negá-la em sua existência ou separá-la do mundo. Tal caminhada ou deslocamento (Ingold, 2015) envolveria o exercício e o desenvolvimento de uma leitura, de um olhar ou de uma epistemologia sagrada, diria Bateson (1987; 2006), que fosse capaz de nos religarà nossa imaginação, aos nossos sonhos e ao nosso mundo. Uma epistemologia que nos ensinasse a ler novamente 0 ambiente, observando e levando a sério aquilo que outras epistemologias se esforçaram para separar, desprezar ou tratar como mera imaginação, puro devaneio de uma mente "fantasiosa", "mística" ou mesmo "religiosa". Tal caminhada envolveria, além disso, a produção e a aprendizagem de um modo de ser/conhecer que não fosse sobre as coisas, e sim com as coisas e os seres que habitam esse mundo. Um modo sagrado de ser e conhecer que não se coloca fora do mundo, tratando-o como simples objeto de conhecimento, mas, ao contrário, se corresponde com ele desde dentro (Ingold, 2012a), estando atento e imerso à vida em toda sua multiplicidade de formas, movimentos e devires.

Gustavo Ruiz Chiesa é Doutor em Ciências Humanas (Antropologia) pela Universidade Federal do Rio de Janeiro. Foi pesquisador de Pós-Doutorado associado ao Programa de Pós-Graduação em Antropologia Social da Universidade Federal do Rio Grande do Sul. Atualmente é Professor Adjunto da Universidade Federal do Pampa.

\section{REFERÊNCIAS BIBLIOGRÁFICAS}

\section{AZEVEDO, Cristiane}

2010 "A procura do conceito de religio: entre o relegere e o religare". Religare, n. 7, v.1: 90-96. 
ARTIGo| Gustavo Ruiz Chiesa | À procura da vida: pensando com Cregory

\section{BATESON, Gregory}

[1973] 1976 Pasos hacia una ecología de la mente. Buenos Aires, Ed. Carlos Lohlé.

[1980] 1986 Mente e natureza: uma unidade necessária.

Rio de Janeiro, Francisco Alves.

[1991] 2006 Una unidad sagrada: pasos ulteriores hacia uma ecología de la mente. Barcelona, Gedisa.

BATESON, Gregory e BATESON, Mary Catherine

1987 Angels Fear: Towards an Epistemology of the Sacred. Nova York, Macmillan.

BONET, Octavio

2014 "Itinerações e malhas para pensar os itinerários de cuidado: a propósito de Tim Ingold". Sociologia \& Antropologia, v.4, n. 2: 327-350.

BONET, Octavio et al.

2014 "A antropologia como participante de uma grande conversa para moldar o mundo: entrevista com Tim Ingold". Sociologia \& Antropologia, v.4, n. 2: 303-326.

CAPRA, Fritjof

1996 A teia da vida. São Paulo, Cultrix.

DELEUZE, Gilles e GUATTARI, Félix

1995 Mil platôs: capitalismo e esquizofrenia. São Paulo, Editora 34.

FLECK, Ludwik

2010 Cênese e desenvolvimento de um fato científico. Belo Horizonte, Fabrefactum.

GELL, Alfred

1998 Art and Agency. Oxford, Clarendon.

GIBSON, James

1979 The Ecological Approach to Visual Perception. Boston, Houghton Mifflin.

\section{GUSDORF, Georges}

1984 L'Homme romantique. Paris, Payot.

INCOLD, Tim

2000 The Perception of the Environment: Essays on Livelihood, Dwelling And Skill. Nova York/Londres, Routledge. 
2001 "From Complementarity to Obviation: On Dissolving the Boundaries between Social and Biological Anthropology, Archaeology, and Psychology". In OYAMA, Susan et al (org). Cycles of Contingency: Developmental Systems and Evolution. Massachusetts, MIT Press.

2006 "Sobre a distinção entre evolução e história". Antropolítica, v. 20: 17-36.

2008 "Tres en uno: cómo disolver las distinciones entre cuerpo, mente y cultura”. In SÁNCHEZ CRIADO, Tomás (org). Tecnogénesis: Ia construcción de las ecologías humanas (volumen 2). Madrid, AIBR.

2011 Being Alive: Essays on Movement, Knowledge and Description. Nova York/Londres, Routledge.

2012a Conociendo desde dentro: reconfigurando las relaciones entre la antropología y la etnografía. Conferencia pronunciada en la Universidad Nacional de General San Martín. Instituto de Altos Estudios Sociales. Buenos Aires, UNSAM.

2012b "Trazendo as coisas de volta à vida: emaranhados criativos num mundo de materiais". Horizontes Antropológicos, v. 18, n. 37: 25-44.

2012C Ambientes para la vida: conversaciones sobre humanidad, conocimiento y antropología. Montevideo, Ediciones Trilce.

2012d "Caminhando com dragões: em direção ao lado selvagem". In STEIL, Carlos Alberto e CARVALHO, Isabel (org.). Cultura, percepção e ambiente: diálogos com Tim Ingold. São Paulo, Terceiro Nome.

2013 Making: Anthropology, Archaeology, Art and Architecture. Nova York/Londres, Routledge.

2015 "O dédalo e o labirinto: caminhar, imaginar e educar a atenção". Horizontes Antropológicos, v. 21, n. 44: 21-36.

MILLER, Daniel (org.)

2005 Materiality. Durham, Duke University Press.

MILTON, Kay

2002 Loving Nature: Towards an Ecology of Emotion. Nova York/Londres, Routledge.

SPINOZA, Baruch

[1677] 2007 Ética. Belo Horizonte, Autêntica Editora.

STEIL, Carlos Alberto e CARVALHO, Isabel

2013 "Percepção e ambiente: aportes para uma epistemologia ecológica". Revista Eletrônica do Mestrado em Educação Ambiental, v. especial: 59-79. 
2014 "Epistemologias ecológicas: delimitando um conceito". Mana, Rio de Janeiro, v. 20, n. 1: 163-183.

TILLEY, Christopher

2007 "Materiality in Materials". Archaeological Dialogues, v. 14, n. 1: 16-20.

VELHO, Otávio

2001 "De Bateson a Ingold: passos na constituição de um paradigma ecológico". Mana, v. 7, n. 2: 133-140.

2010 "Os novos sentidos da interdisciplinaridade e as Ciências Sociais". Anais da $62^{a}$ Reunião Anual da SBPC. Natal, SBPC.

WIENER, Norbert

1948 Cybernetics: Or Control and Communication in the Animal and the Machine. Cambridge, The MIT Press. 


\section{ABSTRACT}

In this article we intend to introduce some of the main notions and conceptualizations elaborated by two influential British anthropologists: Gregory Bateson (1904-1980) and Tim Ingold (1948-). Throughout the text, articulating a reflection around certain categories developed by these authors, we will propose the idea of a sacred perception attentive to the relations that cross and constitute all the beings and things that inhabit the world. A way of perceiving, knowing and engaging with the environment that does not give up dreams and imagination to conceive other possible ways of living the life and to correspond with everything that surrounds us.

Recebido em 8 de fevereiro de 2017. Aceito em 27 de junho de 2017.

\section{KEYWORDS}

Ingold, Bateson, Sacred, Ecology, Cybernetics. 